\title{
The Effect of Intrinsic Motivation and Work Stress on Performance of Employee Pizza Hut MERR Surabaya
}

\author{
Mochammad Fajar, BayuAirlangga, S.E., M.M. \\ Narotama University, Surabaya \\ jarotest30@gmail.com
}

\begin{abstract}
The purpose of this study is 1 . To analyze work motivation on employee performance 2. To analyze work performance with employees 3 . To analyze employee performance at Pizza Hut Merr Surabaya. This research is quantitative research. The population and samples were distributed by 47 respondents. Data collection techniques using a questionnaire. The data analysis used is the Statistical Package for Social Sciences (SPSS). The results of the study showed the effect of the Intrinsic Motivation Variable (X1) on employee performance (Y) showed a significant amount of 0,000 . And Job stress variable (X2) on Employee Performance (Y) shows no significant value of 0.083 . The results of this study indicate that compared to work stress, intrinsic motivation has a stronger dancer on employee performance at Pizza Hut Merr Surabaya.
\end{abstract}

Keywords : intrinsic motivation, work stress, employee performance.

\section{PRELIMINARY}

\subsection{Introduction}

PIZZA HUT INDONESIA makes the following 4 values as the basis for running the organization, also in building relationships with customers, business partners and shareholders. Namely Integrity: Pizza Hut is honest in thinking and working, trustworthy, sincere and professional when dealing with colleagues, customers and suppliers, Excellence: Pizza Hut does work that is more than just a call of duty, doing more than what others expect. We continue to struggle for improvement and thoroughness in everything. Carry out tasks willingly and face all the challenges that exist to achieve the highest standards, Business Growth: Pizza Hut strives to improve capabilities and knowledge, share skills and learn together with coworkers, so that they develop together, both individually and organizationally, Advantages: Pizza Hut always strives as much as possible to provide benefits to shareholders by supervising and increasing sales efforts.

PIZZA HUT MERR SURABAYA is a company engaged in goods and services or services and food for all groups. PIZZA HUT MERR SURABAYA is one of the PIZZA HUT branches throughout Indonesia. It has approximately 400 restaurant branches in Indonesia and one of them in Surabaya is the PIZZA HUT MERR SURABAYA branch. There are approximately 50 employees in one restaurant who are members of a division with each having their own workflow, which can be replaced by each particular part. Therefore competition arises among employees in improving their respective performance and the amount of work pressure from each division outside and inside that must utilize the time as efficiently as possible for service and product services to guests so that when a problem occurs it will have a major impact on employees, employees in Pizza Hut is divided into two parts, namely FOH (Front of House) and $\mathrm{BOH}$ (Back of House) being the main roles in restaurant operations, the first FOH (Front of House) front employees prioritize service to customers who come to go home, have their respective roles and their respective duties from various positions. The second back of house terms focus on making the product, the speed of the product, and the taste of the product, the phenomenon of work stress that often occurs during peak hours or when guests arrive a lot allows the percentage of errors to occur such as wrongly taking orders, wrong deliver food to the table, and to overcome this requires more time so guests will be easily angry when the food ordered does not come. SOPs must be implemented and become habits in terms of processed foods. Audits at each restaurant are referred to as ACE (Assured Customer Insured) and FSCC (Food Safety Compaliment Check). With this, Pizza Hut requires hiring employees who are 
competent in their fields, qualified for their integrity, and responsible for what they have taken, and have the motivation that is in them.

\subsection{Research Purpose}

To partially analyze the influence of intrinsic motivation variables on the performance of PIZZA MERR Surabaya Anniversary employees. To partially analyze the effect of work stress variables on the performance of PIZZA MERR Surabaya Anniversary employees. To simultaneously analyze the influence of variables of intrinsic motivation and work stress on the performance of PIZZA MERR Surabaya Anniversary employees.

\section{LITERATURE REVIEW}

\subsection{Intrinsic Motivation}

Intrinsic motivation is related to psychological rewards such as opportunity to use one's ability, a sense of challenge and achievement, receiving appreciation, positive recognition, and being treated in a caring and considerate manner. The psychological rewards are those that can usually be determined by the actions and behavior of individual managers (Mullins, 2005:88). As Deci, E. L., Koestner, R, \& Ryan (1999:627) observe, intrinsic motivation energizes and sustains activities through the spontaneous satisfactions inherent in effective volitional action. Therefore intrinsic motivation is a part of startegy to boost the employee performance. Which is responsibility, recognation, job enrichment, job satisfaction and achievement.

\subsection{Work Stress}

Job stress is one of the common problems faced by employees with increasing frequency. Recently work stress has become an epidemic in the work environment [3]. Robbins and Judge (2014: 368) defines stress as a dynamic condition in which an individual is faced with opportunities, demands, or resources related to what is desired by the individual and whose results are seen as uncertain and important.

\subsection{Performance Of Employee}

(Waheed and Malik (2011) stated that Job stress occurs when the individual does not have the skills and abilities to perform the job effectively, when he is not given the proper training or some necessary resources have not been given to perform the job or when he is confronted with conflicting job demands.

According Hasibuan (2013:38) reveals that employee performance is a result achieved by someone in carrying out tasks assigned to him.

\section{Research Conceptual}

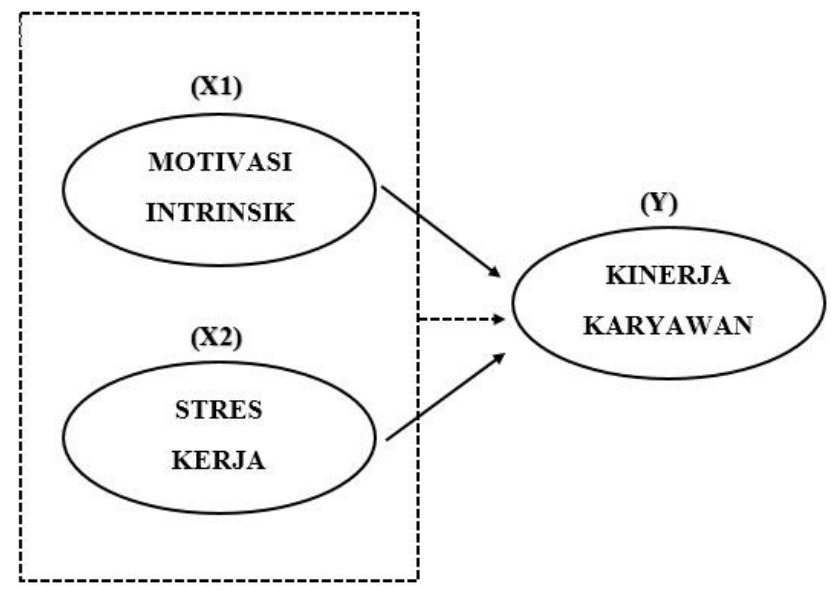


Picture 1 Research Conceptual Information

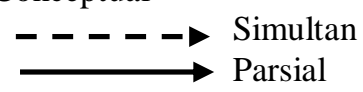

\subsection{Hypotheses}

The hypothesis is a conjecture while the truth is still to be tested. Based on the researchconceptual framework above, the researcher can conclude the hypothesis that will be tested in this study are as follows:

H1: Intrinsic motivation has a significant effect on employee performance.

$\mathrm{H} 2$ : Job stress has a significant effect on employee performance ..

H3:Intrinsic motivation, and work stress, simultaneously, have a significant effect on employee performance.

\section{RESEARCH METHOD}

\subsection{Population}

Sekaran, U., \& Bougie (2009) stated that population is the entire group or people, events, or things that the researcher desires to investigate. The population in this study were all employees of the PIZZA HUT MERR SURABAYA from various divisions.

\subsection{Sample}

According to Sugiyono (2013:315) the sample is partially or representative of the population studied. The population is for example residents in certain regions, number of employees in certain organizations, number of teachers and students in certain schools and so on.

Because the population of this study is less than 100, the researchers took a sample of all employees totaling 47 employees of the PIZZA HUT MERR SURABAYA (saturated sample) or called the census method. The number of samples is considered to meet the requirements in sampling. If the subject is less than 100 ,it is better to take it all so that the research is population research (Arikunto, 2010).

\subsection{Data collection technique}

In this study researchers used data collection techniques and information as follows:

1. Observation: This observation is one way to get data that is relevant to the problem to be studied, in this case it is done at PIZZA HUT MERR SURABAYA.

2. Questionnaire / questionnaire: The researcher distributed questionnaires to all employees of the PIZZA HUT MERR SURABAYA which contained a list of questions according to the indicators of the variables discussed.

\subsection{Variabel dan Definisi Operasional}

This study the indicators of intrinsic motivation are: Responsibility, Achievement, Development and progress, Awards, Career Paths, SOP (Company Operational Standards). In this study the indicators of work stress are: In this study the indicators of work stress are: Task demands, role demands, interpersonal demands, organizational structure, organizational leadership, time demands. In this study employee performance indicators are: Quality, Quantity, Timeliness, Effectiveness, Independence, Work Commitment according to the procedure.

\section{ANALYSIS METHOD}

\subsection{Test Validity}

The definition of validity according to Azwar is the extent to which the accuracy and accuracy of a measuring instrument (test) in performing its measuring function 
4.2 Reliability Test is a series of measurements or a series of measuring instruments that have consistency if the measurements made with the measuring instrument are carried out repeatedly. A variable is said to be reliable if it gives an alpha cronbach value $>0.60$.

4.3 Normal Distribution Test is used by looking at the normal probility plot that compares the cumulative distribution of actual data with the cumulative distribution of normal data.

4.4 Analysis of Multiple Linear Regression aims to find out how far the influence of intrinsic motivation (X1) and work stress (X2) on employee performance (Y).

4.5 T test (partial test) aims to show how far the influence of one independent variable (independent variable) individually in explaining variations in independent variables[10]. In this study the test aims to find out how far the influence of intrinsic motivation (X1) and work stress (X2) on employee performance $(\mathrm{Y})$.

4.6 F Test (Simultaneous Test) is used to test the null hypothesis that the coefficient of compound determination is in the population. $\mathrm{R} 2=0$. Significance test includes testing the significance of the overall regression equation as well as specific partial regression coefficients. The overall test can be done using the F. statistic statistic, this test follows the $\mathrm{F}$ distribution with degrees of freedom $\mathrm{k}$ and (nk-1) (Malhotra, 2006). If the whole null hypothesis is rejected, one or more population compound coefficients has a value not equal to 0 .

4.7 Multicollinearity test is used to test whether the regression model found the presence or absence of correlation between independent variables. If there is 85 correlation, then there is a problem with multicolourism.

4.8 The Heteroscedasticity Test aims to test whether in a regression model, there is an inequality of variance or residuals from one observation to another.

4.9 Normality Test aims to test whether the sample used has a normal distribution or not. In a linear regression model, this assumption is indicated by the error value that is normally distributed.

4.10 Determination Test $\mathbf{R} \& \mathbf{R} 2$ aims to measure how far the ability of the model in explaining variations in independent variables. The value of determination coefficient is between 0 and 1 . The small value of R2 means that the ability of independent variables to explain variations in the dependent variable is very limited. $\mathrm{R}$ means, if $>0.5$, the regression equation proves the effect of the independent variable is significant on the dependent variable. While $\mathrm{R} 2$ is if it is written a number, for example 0.781 means that the influence of the independent variable on the dependent variable is 0.781 or $78.1 \%$. other things that affect the dependent variable are equal $(100 \%-78.1 \%=21.9 \%)$ then there are other variables of $21.9 \%$ which were not discussed in this study.

\section{RESULTS OF RESEARCH AND DISCUSSION}

\section{1 Result of Validity Test}

TableResult of X1 Validity Test

\begin{tabular}{|l|l|l|l|}
\hline ITEM & \multirow{2}{*}{ VALIDITAS } & $\begin{array}{c}\text { R } \\
\text { STANDAR }\end{array}$ & KETERANGAN \\
\hline $\mathrm{X} 1.1$ & 0,718 & 0,287 & Valid \\
\hline $\mathrm{X} 1.2$ & 0,751 & 0,287 & Valid \\
\hline $\mathrm{X} 1.3$ & 0,648 & 0,287 & Valid \\
\hline $\mathrm{X} 1.4$ & 0,435 & 0,287 & Valid \\
\hline $\mathrm{X} 1.5$ & 0,507 & 0,287 & Valid \\
\hline $\mathrm{X} 1.6$ & 0,329 & 0,287 & Valid \\
\hline
\end{tabular}


For the Intrinsic Motivation variable (X1) there is no indicator whose value of validity is below the standard $\mathrm{r} / \mathrm{r}$ count in the indicator indicator X1.1 gets a value of 0.718 . In the indicator X1.2 statement, get a value of 0.751 . On the statement of indicator X1.3, get the value of 0.648 . On the indicator X1.4 statement, get a value of 0.435 . In the statement indicator X1.5 gets a value of 0.507 . In the indicator X1.6 statement, get a value of 0.329 . There is no elimination under the $r$ count that does not need to be eliminated.

Table Result of X2 Validity Test

\begin{tabular}{|l|l|l|l|}
\hline ITEM & VALIDITAS & $\begin{array}{l}\text { R } \\
\text { STANDAR }\end{array}$ & KETERANGAN \\
\hline $\mathrm{X} 2.1$ & 0,620 & 0,287 & Valid \\
\hline $\mathrm{X} 2.2$ & 0,744 & 0,287 & Valid \\
\hline $\mathrm{X} 2.3$ & 0,597 & 0,287 & Valid \\
\hline $\mathrm{X} 2.4$ & 0,675 & 0,287 & Valid \\
\hline $\mathrm{X} 2.5$ & 0,675 & 0,287 & Valid \\
\hline X2.6 & 0,577 & 0,287 & Valid \\
\hline
\end{tabular}

Validity test of work stress (X2) above, it can be seen that all statements from indicators of work stress variables have values above $\mathrm{r}$ count, so they can be valid

Table Result of Y Validity Test

\begin{tabular}{|l|l|l|l|}
\hline ITEM & VALIDITAS & $\begin{array}{l}\text { R } \\
\text { STANDAR }\end{array}$ & KETERANGAN \\
\hline Y1 & 0,484 & 0,287 & Valid \\
\hline Y2 & 0,453 & 0,287 & Valid \\
\hline Y3 & 0,308 & 0,287 & Valid \\
\hline Y4 & 0,508 & 0,287 & Valid \\
\hline Y5 & 0,511 & 0,287 & Valid \\
\hline Y6 & 0,731 & 0,287 & Valid \\
\hline
\end{tabular}

From the table of employee performance validity test (Y) above it can be seen that the value of the indicator statement of the variable has a value above $\mathrm{r}$ count, then all statements from the indicator are declared valid.

\subsection{Result of Realibility Test}

Table Result of Realibility Test

\section{Reliability Statistics}

\begin{tabular}{|l|l|}
\hline $\begin{array}{l}\text { Cronbach's } \\
\text { Alpha }\end{array}$ & N of Items \\
\hline .909 & 18 \\
\hline
\end{tabular}

From the reliability test table the research variable above shows that all the values of croanbach alpha from the variables both dependent and independent are stated to be reliable or acceptable because they have values above 0.6, which means that the statements of the research questionnaire are said to be reliable or reliable. 


\subsection{Result of Distribution Normal Test}

Table Result of Distribution Normal Test

One-Sample Kolmogorov-Smirnov Test

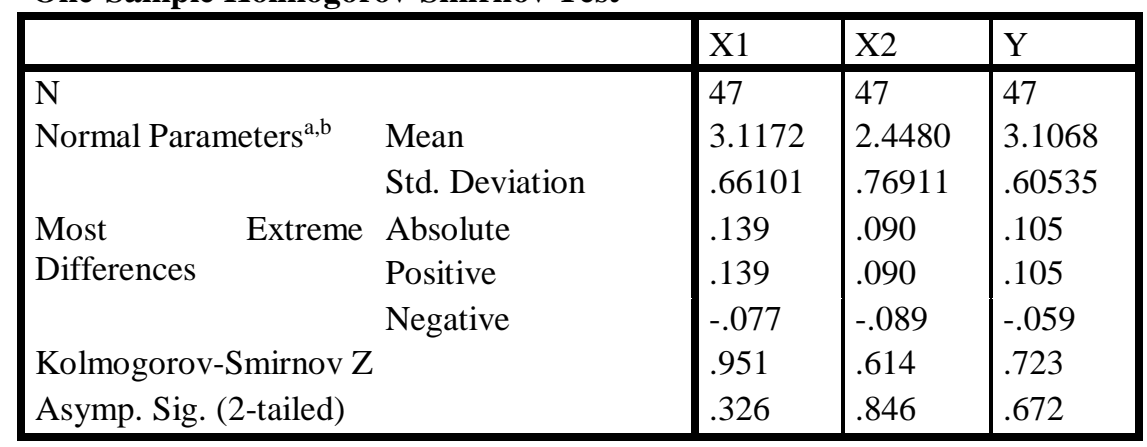

a. Test distribution is Normal.

b. Calculated from data.

From the table above, the sig value of each variable is more than 0.05 so that the variable can be said to be normally distributed.

\subsection{Result of Multiple Linear Regression Test}

Table Multiple Linear Regression Test

From the coefficient table above the multiple linear regression equation is obtained as follows:

\begin{tabular}{|c|c|c|c|c|c|c|}
\hline \multicolumn{7}{|c|}{ Coefficients $^{\mathrm{a}}$} \\
\hline \multirow{2}{*}{\multicolumn{2}{|c|}{ Model }} & \multicolumn{2}{|c|}{ Unstandardized Coefficients } & $\begin{array}{l}\text { Standardized } \\
\text { Coefficients }\end{array}$ & \multirow[b]{2}{*}{$\mathrm{t}$} & \multirow[b]{2}{*}{ Sig. } \\
\hline & & $\mathrm{B}$ & Std. Error & Beta & & \\
\hline \multirow[t]{3}{*}{1} & (Constant) & .964 & .284 & & 3.391 & .001 \\
\hline & $\mathrm{X} 1$ & .548 & .117 & .598 & 4.701 & .000 \\
\hline & $\mathrm{X} 2$ & .178 & .100 & .226 & 1.774 & .083 \\
\hline
\end{tabular}

a. Dependent Variable: $Y$

$$
\begin{aligned}
& \mathrm{Y}=0,964+0,548 \mathrm{X} 1+0,178 \mathrm{X} 2+\mathrm{e} \\
& \mathrm{Y}=\text { Employee performance } \\
& \mathrm{X} 1=\text { Intrinsic Motivation } \\
& \mathrm{X} 2=\text { Work stress } \\
& \mathrm{E}=\text { Error }
\end{aligned}
$$

\begin{tabular}{|c|c|c|c|c|c|c|}
\hline \multicolumn{7}{|c|}{ Coefficients $^{\mathrm{a}}$} \\
\hline \multirow{2}{*}{\multicolumn{2}{|c|}{ Model }} & \multicolumn{2}{|c|}{ Unstandardized Coefficients } & $\begin{array}{l}\text { Standardized } \\
\text { Coefficients }\end{array}$ & \multirow[b]{2}{*}{$\mathrm{t}$} & \multirow[b]{2}{*}{ Sig. } \\
\hline & & $\mathrm{B}$ & Std. Error & Beta & & \\
\hline \multirow[t]{3}{*}{1} & (Constant) & .964 & .284 & & 3.391 & .001 \\
\hline & $\mathrm{X} 1$ & .548 & .117 & .598 & 4.701 & .000 \\
\hline & $\mathrm{X} 2$ & .178 & .100 & .226 & 1.774 & .083 \\
\hline
\end{tabular}

\subsection{Result of Ttest(partialtest)}

Table coefficients Result of T Test

a. Dependent Variable: Y

The above coefficients obtained partial hypothesis test results as follows:

1. Effect of intrinsic motivation variable (X1) on employee performance (Y) 
The results of the analysis obtained a significant value of 0,000 (less than 0.05 ) which means that the intrinsic motivation variable $(\mathrm{X} 1)$ has a significant effect on employee performance $(\mathrm{Y})$.

2. Effect of work stress variables (X2) on employee performance (Y)

The results of the analysis of work stress variables were obtained with a significant value of 0.083

(greater than 0.05) which means the variable work stress (X2) has no significant effect on employee performance $(\mathrm{Y})$.

\title{
5.6 Result of FTest (Simultaneous Test)
}

\author{
Table Anofa F Test
}

ANOVA $^{b}$

\begin{tabular}{|ll|r|r|r|r|r|}
\hline Model & & Sum of Squares & Df & Mean Square & F & Sig. \\
\hline 1 & Regression & 9.821 & 2 & 4.910 & 30.710 & $.000^{\mathrm{a}}$ \\
& Residual & 7.036 & 44 & .160 & & \\
& Total & 16.856 & 46 & & & \\
\hline
\end{tabular}

a. Predictors: (Constant), X2, X1

b. Dependent Variable: Y

From the ANOVA table above, it can be said that the results of the hypothesis test simultaneously with the value of F count of 30.710 with a significant level of 0.00 . Significant value F greater than 0.05 means that there is a significant effect simultaneously between intrinsic motivation (X1), work stress (X2) on employee performance $(\mathrm{Y})$.

\subsection{Result of Multicollinearity Test}

Table Coefficients Multicollinearity Test

\begin{tabular}{|ll|r|r|}
\multicolumn{4}{|c|}{ Coefficients $^{\mathbf{a}}$} \\
\hline \multicolumn{2}{|l|}{ Model } & & \multicolumn{1}{|c|}{ Collinearity Statistics } \\
\cline { 3 - 4 } & & Tolerance & \multicolumn{1}{c|}{ VIF } \\
\hline 1 & $\mathrm{X} 1$ & .586 & 1.707 \\
& $\mathrm{X} 2$ & .586 & 1.707 \\
\hline
\end{tabular}

a. Dependent Variable: Y

In the table above shows that the VIF value for the free variable is smaller than 5 , so that it can be said that there have been no symptoms of multicollinearity between each of the independent variables.

\subsection{Result of Heteroscedasticity Test}

Picture ScatterplotHeteroscedasticity Test

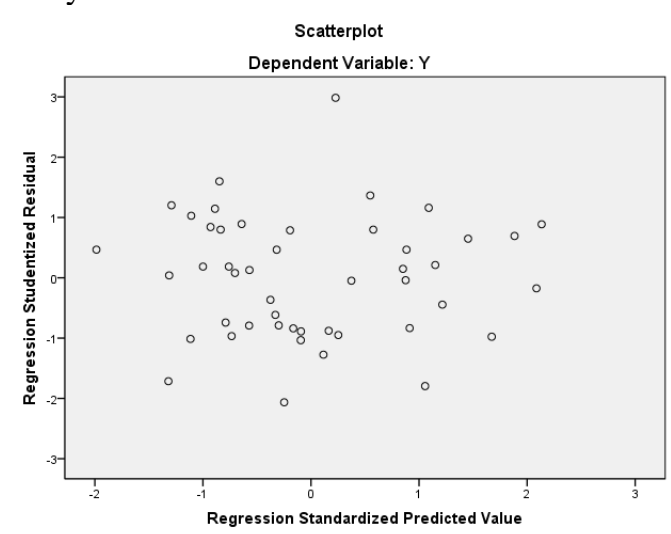


In the picture above it is said heteroscedasticity if the image is scattered and not stained from the line number 0 on $\mathrm{X}$ and $\mathrm{Y}$, there is no heterokesdisity.

\subsection{Result of NormalityTest}

Picture P-Plot Normality Test

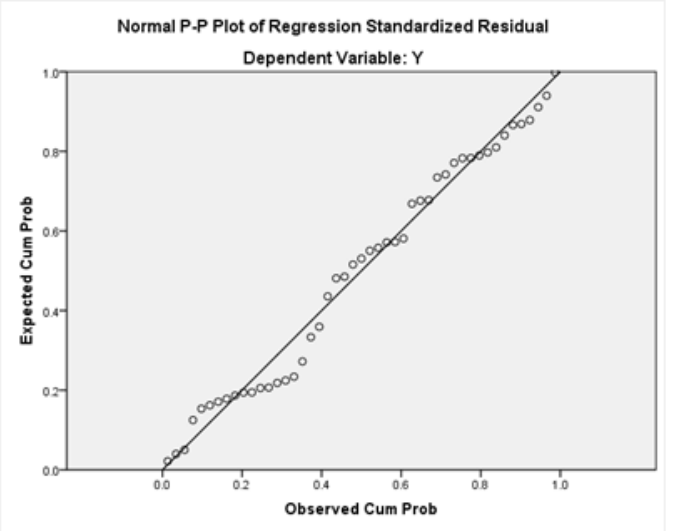

The test results of the data from the table above show that data points spread around the diagonal line can be said that the data in this study have a normal distribution.

\subsection{Result of Determination Test $R \& R 2$}

Table summary Determination Test $\mathrm{R}$ dan $\mathrm{R}^{2}$

\section{Model Summary}

\begin{tabular}{|c|c|c|c|c|}
\hline Model & $\mathrm{R}$ & $\begin{array}{c}\mathrm{R} \\
\text { Square }\end{array}$ & $\begin{array}{l}\text { Adjusted R } \\
\text { Square }\end{array}$ & Std. Error of the Estimate \\
\hline $\begin{array}{c}\text { dimens } 1 \\
\text { ion0 }\end{array}$ & $.763^{\mathrm{a}}$ & .583 & .564 & .3998745 \\
\hline
\end{tabular}

a. Predictors: (Constant), X2, X1

Based on the results of the test data in the table summary model above, the adjusted $\mathrm{R}$ square value is 0.564 which means $56 \%$ variation of the intrinsic motivation variable (X1), work stress (X2) affects employee performance (X1) with $56 \%$ remaining $44 \%$ affected by other variables which was not discussed in this study.

\section{FINALITY}

\subsection{Conclusions}

The conclusions of this study are:

1. Intrinsic motivation partially has a positive effect on the performance of employees of PIZZA HUT MERR SURABAYA.

2. Partially job stress has no significant effect on the performance of employees of PIZZA HUT MERR SURABAYA. 
3. Partially intrinsic motivation has the most significant effect on the performance of employees of the PIZZA HUT MERR SURABAYA, compared to the work stress variables examined in this study.

4. From the results of the test of determination known intrinsic motivation, work stress affects employee performance by $56 \%$, the remaining $44 \%$ is influenced by other variables not discussed in this study.

\subsection{Suggestions}

Suggestions from this study are:

If this company improves employee performance, the company should increase intrinsic motivation in each employee first, with intrinsic motivation employees will always be enthusiastic in completing any task in each job without any work stress based on each operation, reducing work stress that often occurs It is possible to work stress on every employee with anticipation when crowded hours of visitors or customers, job desks are in accordance with the assigned divisions and allow several months to hold gatherings or outbound out of town to allow stressful actions to disappear even though the percentage is small.

\section{REFERENCES}

[1] L. J. Mullins, Management and Organisational Behaviour, 7th Ed. Prentice Hall. United Kingdom., 2005.

[2] R. M. Deci, E. L., Koestner, R, \& Ryan, “A Meta-Analytic Review of Experiments Examining the Effects of Extrinsic Rewards on Intrinsic Motivation.," 1999.

[3] Ugur Yozgat dkk., "Job Stress And Job Performance Among Employees In Public Sector InIstanbul: Examining The Moderating Role Of Emotional intelligence," 2013. [Online]. Available: https://www.sciencedirect.com/science/article/pii/S1877042813005922 . [Accessed: 03-Feb-2019].

[4] S. P. dan T. A. J. Robbins, Perilaku Organisasi. Salemba Empat; Jakarta, 2014.

[5] A. W. and K.-U.-R. M. Malik, Omer Farooq., "The Mediating Effects of Job Satisfaction on Role Stressors and Affective Commitment," 2011. [Online]. Available: http://www.ccsenet.org/journal/index.php/ijbm/article/view/8086. [Accessed: 03-Feb-2019].

[6] H. S. P. Malayu, Manajemen Sumber Daya Manusia. PT. Bumi Aksara: Jakarta, 2013.

[7] R. Sekaran, U., \& Bougie, Research Methods for Business: A Skill Building Approach, 5th editio. New Jersey: John Wiley and Sons, 2009.

[8] Sugiyono, METODE PENELITIAN KUANTITATIF, KUALITATIF DAN R\&D. Alfabeta; Bandung, 2013.

[9] S. Arikunto, Metodologi penelitian kuantitatif. Jakarta: Rineka Cipta., 2010.

[10] I. Ghozali, Aplikasi Analisis Multivariate dengan Program SPSS. semarang: Badan Penerbit Universitas Diponegoro, 2005. 